\title{
PENTINGNYA KEBUGARAN AEROBIK BAGI SETIAP ATLET YANG BERTANDING PADA KEJUARAAN MULTI EVENT
}

\author{
Oleh: Suharjana \\ Dosen Jurusan Pendidikan Kesehatan dan Rekreasi FIK UNY
}

Abstrak

Untuk mengetahui perkembangan prestasi atlet yang akan berlaga dalam arena multi event seperti PON biasanya dilakukan pertandingan uji coba melawan atlet daerah atau bertanding melawan atlet mancanegara. Selain itu untuk melihat perkembangan atlet biasanya juga dilakukan tes fisik umum untuk seluruh atlet cabang olahraga. Salah satu item tes fisik yang biasanya selalu digunakan adalah tes kebugaran aerobik.

Kebugaran aerobik merupakan unsur kondisi fisik umum yang harus dimiliki oleh setiap atlet dalam cabang olahraga. Jika kebugaran aerobik seorang atlet bagus, maka atlet tersebut tidak akan mudah lelah dalam menjalankan latihan atau pun dalam pertandingan. Bagi atlet yang unsur biomotornya dominan aerobik, sebaiknya kebugaran aerobik bergerak antara skala baik dan baik sekali, sedangkan bagi atlet yang unsur biomotarnya dominan non aerobik sebaiknya kebugaran aerobiknya dalam skala sedang sampai baik.

Kata kunci : kebugaran aerobik, puslatda

Perhelatan olahraga yang digelar dengan melibatkan hampir semua cabang olahraga, disebut dengan kejuaraan multi event. Di tingkat dunia kejuaraan ini diberi nama Olimpiade, untuk tingkat Asia disebut Asia Games, sedangkan di tingkat Asia Tenggara disebut Asean Games dan untuk level Indonesia diberi titel PON (Pekan Olahraga Nasional). PON digelar setiap 4 tahun. Pada tahun 2012 Pekan Olahraga Nasional di gelar pada tanggal 9 s/d 20 September 2012 di Pekan Baru Riau. Pada tahun 2012 ini PON genap yang ke XVIII.

Sebagai pesta rakyat PON merupakan tolok ukur pembinaan olahraga suatu daerah. Setiap Provinsi berlomba-lomba untuk memperoleh medali sebanyak-banyaknya. Pada saat ini perolehan medali pada ajang pesta oahraga tidak sekedar gengsi atau kebanggaan daerah. Medali identik dengan pundi-pundi uang, karena setiap daerah akan memberi bonus atau sekedar tali asih sebagai atlit yang memperoleh medali yang nilainya bisa mencapai ratusan juta rupiah. Untuk mencapai target medali setiap daerah akan mempersiapkan para atletnya yang akan terjun pada event nasional ini.

Untuk mencapai target medali dalam PON biasanya dilakukan pemusatan latihan daerah atau dikenal dengan istilah PUSLATDA PON (Pemusatan Latihan Daerah PON), yang biasanya berlangsung lama, berbulan-bulan bahkan bisa memakan waktu setahun sampai dua tahun. PUSLATDA PON diikuti oleh para atlet yang lolos kualifikasi PON, karena syarat untuk tampil di PON harus terlebih dulu lolos kualifikasi PON (PRA PON). 


\section{MEDIKORA Vol. IX, No 1 Oktober 2012}

Untuk mengetahui perkembangan prestasi atlet biasanya dilakukan pertandingan dalam skala uji coba melawan atlet daerah lain atau bertanding melawan atlet mancanegara. Disisi lain untuk melihat perkembangan atlet biasanya dilakukan tes fisik umum untuk seluruh atlet cabang olahraga. Salah satu item tes fisik yang biasanya selalu digunakan adalah tes kebugaran aerobik.

Tidak semua atlet membutuhkan kebugaran aerobik dalam level yang tinggi, tetapi kebugaran aerobik merupakan unsur kondisi fisik umum yang harus dimiliki oleh setiap atlet dalam cabang olahraga. Jika kebugaran aerobik seorang atlet bagus, maka atlet tersebut tidak akan mudah lelah dalam menjalankan latihan atau pun pertandingan. Secara general hasil tes kebugaran aerobik belum dimaknai secara mendalam, seberapa kebermaknaannya dalam setiap cabang olahraga. Berdasarkan permasalahan seperti tersebut di atas maka rumusan masalah dalam penelitian ini adalah: Apakah kebugaran aerobik itu penting bagi semua atlet tanpa melihat cabang olahraganya?

\section{PEMBAHASAN}

Kebugaran jasmani diartikan sebagai kemampuan fisik yang optimal dalam hidup seseorang, dengan ditandai oleh pencapaian nilai tes kebugaran jasmani dalam tingkat tertentu, dan terhindarkan dari masalah-masalah kesehatan. Menurut Sumosardjuno (1989: 9) kebugaran fisik adalah kemampuan seseorang untuk menunaikan tugas sehari-hari tanpa merasa lelah serta masih mempunyai cadangan tenaga untuk menikmati waktu senggang dan untuk keperluan-keperluan mendadak. Dapat pula ditambahkan bahwa kesegaran jasmani merupakan kemampuan untuk menunaikan tugas dengan baik walaupun dalam keadaan sukar, sedangkan orang yang kesegaran jasmaninya kurang tidak dapat melakukannya.

Hairy (1989: 9) menyatakan kebugaran jasmani adalah kemampuan untuk melaksanakan tugas sehari-hari dengan giat dan dengan penuh kewaspadaan, tanpa mengalami kelelahan yang berarti, dan dengan energi yang cukup untuk menikmati waktu senggangnya dan menghadapi hal-hal yang darurat yang tak terduga. Dengan demikian kebugaran jasmani dapat diartikan sebagai kesanggupan seseorang untuk menjalankan hidup sehari-hari tanpa menimbulkan kelelahan yang berlebihan dan masih memiliki kemmapuan untuk mengisi pekerjaan ringan lainnya.

Kebugaran jasmani dibagi dalam dua kelompok, yaitu kebugaran jasmani yang terkait dengan kesehatan dan kebugaran jasmani yang terkait dengan keterampilan. Dalam http://en.wikipedia.org/wiki/Physical dinyatakan bahwa Physical fitness comprises two related concepts: general fitness (a state of health and well-being), and specific fitness (a 


\section{MEDIKORA Vol. IX, No 1 Oktober 2012}

task-oriented definition based on the ability to perform specific aspects of sports or occupations). Physical fitness is generally achieved through correct nutrition, exercise, and enough rest. Fitness was commonly defined as the capacity to carry out the day's activities without undue fatigue. However, as automation increased leisure time, changes in lifestyles following the industrial revolution rendered this definition insufficient. In current contexts, physical fitness is considered a measure of the body's ability to function efficiently and effectively in work and leisure activities, to be healthy, to resist hypokinetic diseases, and to meet emergency situations.

Berikut ini The President's Council on Physical Fitness and Sports (http://en.wikipedia.org/wiki/Physical) menyatakan: a study group sponsored by the government of the United States declines to offer a simple definition of physical fitness. Instead, it developed the following chart:

Tabel 1. Pengelompokan komponen kebugaran Jasmani

\begin{tabular}{|c|c|c|c|}
\hline & Health related & Skill related & Sports \\
\hline $\begin{array}{l}\text { 1. Metabolic } \\
\text { 2. Morphological } \\
\text { 3. Bone integrity } \\
\text { 4. Other }\end{array}$ & $\begin{array}{l}\text { 1. Body composition } \\
\text { 2. Cardiovascular fitness } \\
\text { 3. Flexibility } \\
\text { 4. Muscular endurance } \\
\text { 5. Muscle strength }\end{array}$ & $\begin{array}{l}\text { 1. Agility } \\
\text { 2. Balance } \\
\text { 3. Coordination } \\
\text { 4. Power } \\
\text { 5. Speed } \\
\text { 6. Reaction time } \\
\text { 7. Other }\end{array}$ & $\begin{array}{l}\text { 1. Team sport } \\
\text { 2. Individual sport } \\
\text { 3. Lifetime } \\
\text { 4. Other }\end{array}$ \\
\hline
\end{tabular}

Menurut Sajoto (1988: 43) komponen kesegaran jasmani terdiri dari: 1) Kesegaran kardiovaskuler, 2) Kesegaran kekuatan otot, 3) Keseimbangan berat badan, 4) Kesegaran kelentukan, 5) Koordinasi, 6) Keseimbang, 7) Kecepatan, dan 8) Kelincahan. Dengan memperhatikan komponen-komponen kesegaran jasmani di atas menunjukkan bahwa kebugaran aerobik menjadi komponen kebugaran utama baik untuk menjaga kesehatan ataupun untuk performa atlit, baik dalam cabang olahraga tim maupun individu. Berikut ini gambaran $\mathrm{VO}_{2}$ Max para atlet dunia yang diambil dari http://www.brianmac.co (2012) sebagai berikut:

Tabel 2. Performa $\mathrm{VO}_{2}$ Max pada cabang olahraga (http://www.brianmac.co., 2012) 


\begin{tabular}{|c|c|c|c|}
\hline $\begin{array}{c}\text { VO } \mathbf{2} \text { Max } \\
(\mathbf{m l} / \mathbf{k g} / \mathbf{m i n})\end{array}$ & Athlete & Gender & Sport/Event \\
\hline 96.0 & Espen Harald Bjerke & Male & Cross Country Skiing \\
\hline 96.0 & Bjorn Daehlie & Male & Cross Country Skiing \\
\hline 92.5 & Greg LeMond & Male & Cycling \\
\hline 92.0 & Matt Carpenter & Male & Marathon Runner \\
\hline 92.0 & Tore Ruud Hofstad & Male & Cross Country Skiing \\
\hline 91.0 & Harri Kirvesniem & Male & Cross Country Skiing \\
\hline 88.0 & Miguel Indurain & Male & Cycling \\
\hline 87.4 & Marius Bakken & Male & 5K Runner \\
\hline 85.0 & Dave Bedford & Male & 10K Runner \\
\hline 85.0 & John Ngugi & Male & Cross Country Runner \\
\hline 73.5 & Greta Waitz & Female & Marathon runner \\
\hline 71.2 & Ingrid Kristiansen & Female & Marathon Runner \\
\hline 67.2 & Rosa Mota & Female & Marathon Runner \\
\hline
\end{tabular}

Kebugaran aerobik adalah suatu aktivitas yang menekankan pada kemampuan tubuh dalam melakukan kerja dalam waktu yang agak lama dan terus menerus dan dalam keadaan aerobik. Kebugaran aerobik merupakan manifestasi dari daya tahan kardio-respirasi. Daya tahan kardiorespirasi adalah kemampuan melakukan aktivitas berat dan berlangsung lama yang tergantung efisiensi kerja pembuluh darah, jantung, dan paru-paru. Sajoto (1988: 45) menyatakan bahwa ketahanan jantung dan peredaran darah merupakan jumlah kerja maksimal yang dapat dilakukan seseorang secara terus menerus dengan melibatkan kelompok otot besar serta tergantung pada kemampuan menggunakan oksigen secara efisien. Makin banyak kerja yang dilakukan, maka banyak oksigen yang dipakai oleh tubuh.

Efisiensi sistem kardio-respirasi merupakan komponen penting dalam kesegaran jasmani karena : (a) otot tidak dapat meneruskan kontraksi tanpa diberi oksigen, dan (b) oksigen diangkut ke sel-sel melalui sistem kardio-respirasi. Menurut Abdulkadir Ateng (1992: 66) seseorang yang memiliki kesegaran aerobik yang baik akan menunjukkan beberapa hal sebagai berikut: 1) Volume/menit lebih besar, karenanya lebih banyak oksigen yang dapat diantar ke sel-sel otot dan pembuangan sisa yang lebih memadai, 2) Denyut nadi lebih lambat, ini memberikan waktu tambahan bagi ventrikel untuk istirahat, 3) Tekanan darah lebih rendah hingga mengurangi waktu bila tekanan mencapai batas fisiologi, 4) 


\section{MEDIKORA Vol. IX, No 1 Oktober 2012}

Permukaan paru-paru yang lebih besar, hal ini memungkinkan lebih banyak oksigen yang berasimilasi dengan darah, 5) Jumlah butir darah merah dan hemoglobin lebih banyak hingga menambah jumlah oksigen yang diangkut ke jaringan.

Kebugaran aeobik berarti kemampuan seseorang untuk menggunakan oksigen yang cukup untuk memenuhi kebutuhan pada waktu melakukan latihan olahraga. Menurut Bompa (2000: 30) kebugaran aerobik adalah kemampuan mengkonsumsi oksigen tertinggi selama kerja maksimal yang dinyatakan dalam liter/menit atau $\mathrm{ml} / \mathrm{kg} / \mathrm{mnt}$. Kebugaran aerobik disebut juga daya tahan paru jantung atau daya tahan kardiorespirasi, atau daya tahan kardiovaskuler. Dalam berbagai buku pelatihan olahraga, kebugaran aerobik diistilahkan dengan nama kapasitas aerobik maksimal atau $\mathrm{VO}_{2} \operatorname{Max}$ (Fox, 1987: 64).

Dalam olahraga dikenal adanya aktivitas yang bersifat aerobik dan anaerobik. Istilah aerobik dalam olahraga berkaitan dengan aktivitas atau latihan yang dilakukan dengan pembentukan energi harus tersedia oksigen. Sedangkan aktivitas anaerobik merupakan latihan atau olahraga yang dilakukan tanpa memerlukan oksigen dalam setiap penyediaan energi. Untuk mengetahui kebugaran aerobik seseorang harus dilakukan pengukuran atau tes kebugaran aerobik. Tes kebugaran aerobik telah banyak diciptakan oleh para pakar kesehatan olahraga, seperti tes lari 2,4 KM dari Cooper, Multistage Fitness Test, Harvard Step Test, atau tes 15 menit Balke. Dalam http://goligog.wordpress.com.2010 dinyatakan bahwa $\mathrm{VO}_{2} \mathrm{Max}$ ini adalah suatu tingkatan kemampuan tubuh yang dinyatakan dalam liter per menit atau milliliter/menit/kg berat badan. Kebutuhan akan Oksigen dan menghasilkan $\mathrm{CO}_{2}$ dapat diukur melalui pernafasan kita. Dengan mengukur jumlah oksigen yang dipakai selama latihan, kita mengetahui jumlah oksigen yang dipakai oleh otot yang bekerja. Makin tinggi jumlah otot yang dipakai maka makin tinggi pula intensitas kerja otot. Tentu, semakin tinggi VO2max, seorang atlet yang bersangkutan juga akan memiliki daya tahan dan stamina yang baik. Sekalipun memiliki stamina yang baik, atlit tetap harus memiliki penguasaan teknik cabangnya dengan baik. Sebab, dengan teknik yang baik, sang atlet akan efisien dalam bertanding. Berikut ini tabel normatif $\mathrm{VO}_{2}$ Max untuk atlet maupun non atlet yang diambil dari Wilmore and Costill (2005) dalam http://www.brianmac.co (2012) sbb:

Tabel 3. Performa $\mathrm{VO}_{2}$ Max untuk non atlet berdasar usia

\begin{tabular}{|c|c|c|}
\hline Age & Male & Famale \\
\hline $10-19$ & $47-56$ & $38-46$ \\
\hline $20-29$ & $43-52$ & $33-42$ \\
\hline $30-39$ & $39-48$ & $30-38$ \\
\hline
\end{tabular}




\begin{tabular}{|l|l|l|}
\hline $40-49$ & $36-44$ & $26-35$ \\
\hline $50-59$ & $34-41$ & $24-33$ \\
\hline $60-69$ & $31-38$ & $22-30$ \\
\hline $70-79$ & $28-35$ & $20-27$ \\
\hline
\end{tabular}

Tabel 4. Performa $\mathrm{VO}_{2}$ Max untuk atlet berdasar usia

\begin{tabular}{|l|l|l|l|}
\hline \multicolumn{1}{|c|}{ Sport } & Age & Male & Female \\
\hline Baseball & $18-32$ & $48-56$ & $52-57$ \\
\hline Basketball & $18-30$ & $40-60$ & $43-60$ \\
\hline Cycling & $18-26$ & $62-74$ & $47-57$ \\
\hline Canoeing & $22-28$ & $55-67$ & $48-52$ \\
\hline Football (USA) & $20-36$ & $42-60$ & \\
\hline Gymnastics & $18-22$ & $52-58$ & $35-50$ \\
\hline Ice Hockey & $10-30$ & $50-63$ & $46-60$ \\
\hline Orienteering & $20-60$ & $47-53$ & $58-65$ \\
\hline Rowing & $20-35$ & $60-72$ & $50-55$ \\
\hline Skiing alpine & $18-30$ & $57-68$ & $60-75$ \\
\hline Skiing nordic & $20-28$ & $65-94$ & $50-60$ \\
\hline Soccer & $22-28$ & $54-64$ & $44-55$ \\
\hline Speed skating & $18-24$ & $56-73$ & $40-60$ \\
\hline Swimming & $10-25$ & $50-70$ & $50-56$ \\
\hline Track \& Field - Discus & $22-30$ & $42-55$ & \\
\hline Track \& Field - Running & $18-39$ & $60-85$ & \\
\hline Track \& Field - Running & $40-75$ & $40-60$ & \\
\hline Track \& Field - Shot & $22-30$ & $40-46$ & \\
\hline Volleyball & $18-22$ & $52-65$ & \\
\hline Weight Lifting & $20-30$ & & \\
\hline Baseball & $18-32$ & & \\
\hline Wrestling & $20-30$ & & \\
\hline
\end{tabular}

Latihan aerobik adalah latihan yang bertujuan untuk merangsang kerja jantung dan paru-paru, sehingga kerjanya menjadi efisien. Intensitas latihan aerobik biasanya didasarkan 


\section{MEDIKORA Vol. IX, No 1 Oktober 2012}

pada denyut nadi, karena denyut nadi dapat digunakan sebagai tolok ukur kerja jantung. Untuk mengembangkan kapasitas aerobik ini dapat dilakukan dengan melakukan latihanlatihan yang berjangka waktu lama dan terus-menerus. Dalam http://www.brianmac.co.dinyatakan bahwa numerous studies show that you can increase your $\mathrm{VO}_{2}$ Max by working out at an intensity that raises your heart rate to between 65 and 85\% of its maximum for at least 20 minutes three to five times a week. A mean value of $\mathrm{VO}_{2}$ Max for male athletes is about 3.5 litres/minute and for female athletes it is about 2.7 litres/minute.

Salah satu instrumen yang digunakan untuk mengetahui $\mathrm{VO}_{2} \mathrm{Max}$ adalah dengan tes jalan lari 15 menit dari Balke. Tes jalan-lari adalah salah satu tes untuk mengukur tingkat kebugaran aerobik atau $\mathrm{VO}_{2}$ Max seorang atlet. Tes ini memerlukan peralatan sebagai berikut:

1. Lapangan atau lintasan lari yang lintasan dapat dilihat dengan jelas oleh testor. Gunakan lintasan lari dengan panjang keliling $400 \mathrm{~m}$

2. Penanda jarak yang berupa angka untuk menandai jarak lintasan

3. Stopwatch atau alat pengukur waktu dalam satuan menit.

4. Blangko pencatatan hasil

Adapun protokol pelaksanaan lari 15 menit adalah sebagai berikut:

1. Peserta tes berdiri digaris Start dan bersikap untuk berlari secepat-cepatnya selama 15 menit.

2. Bersamaan dengan aba-aba "Ya...." Peserta tes mulai berlari dan petugas tes mulai menghidupkan stopwatch.

3. Setelah waktu menunjukkan lama berlari 15 menit, petugas memberi aba-aba berhenti, dan bersamaan dengan itu stopwatch dimatikan dan peserta berhenti (jalan ditempat) dan petugas akan memberi penanda yang telah disiapkan sebagai penanada jarak yang telah ditempuhnya.

4. Petugas mencatat jarak yang ditempuh peserta tes dalamsatuan meter.

Untuk menentukan kebugarn aerobik, terlebih dahulu dihitung besarnya $\mathrm{VO}_{2} \mathrm{Max}$ setiap atlet. Selanjutnya untuk menghitung besarnya $\mathrm{VO}_{2}$ Max setiap atlet adalah jarak yang ditempuh oleh atlet dimasukan dalam rumus :

$$
\text { VO2MAX }=\left[\left\{\frac{X}{15} \times 1,33\right\} \times 0,17\right]+33,3
$$

$$
\text { Rumus mencari } \mathrm{VO}_{2} \text { Max menurut Tes Balke }
$$


Ket : $\mathrm{X}=$ jarak yang ditempuh dalam satuan meter

Selanjutnya untuk mengetahui klaisifikasi atau tingkat kebugaran setiap atlet, maka hasil perhitungan $\mathrm{VO}_{2}$ max untuk setiap atlet berdasarkan penggunaan rumus tersebut dicocokan dengan tabel norma kebugaran aerobik menurut tes Balke seperti berikut ini:

Tabel 5. Norma kebugaran jasmani menurut tes Balke

\begin{tabular}{|c|c|c|}
\hline Laki-Laki & Norma & Perempuan \\
\hline$>61.00$ & Baik sekali & $>54.30$ \\
\hline $60.90 \mathrm{~s} / \mathrm{d} 55.10$ & Baik & $54.20 \mathrm{~s} / \mathrm{d} 49.30$ \\
\hline $55.00 \mathrm{~s} / \mathrm{d} 49.20$ & Sedang & $49.20 \mathrm{~s} / \mathrm{d} 44.20$ \\
\hline $49.10 \mathrm{~s} / \mathrm{d} 43.30$ & Kurang & $44.10 \mathrm{~s} / \mathrm{d} 39.20$ \\
\hline$<43.20$ & Kurang Sekali & $<39.10$ \\
\hline
\end{tabular}

Penelitian yang dilakukan Suharjana (2012) dengan subjek dalam penelitian terdiri atas 108 atlet putra dan 82 atlet putri, sehingga total sampel ada 190 atlet. Dari seluruh atlet yang berjumlah 190 orang yang masuk dalam katagori baik sekali (BS) 0 orang atau 0\%, yang masuk dalam klasifikasi baik (B) 0 orang atau $0 \%$, yang masuk klasifikasi sedang (S) ada 25 orang atau $13.16 \%$, yang masuk dalam kalsifikasi kurang ada 69 orang atau 36.31 $\%$ dan yang masuk dalam klasifikasi kurang sekali (KS) ada 108 orang atau $50.53 \%$.

Jika dilihat khusus atlet laki-laki hasil penelitian menunjukan bahwa dari seluruh atlet laki-laki yang berjumlah 108 orang yang masuk dalam klasifikasi baik sekali (BS) 0 orang atau $0 \%$, yang masuk dalam klasifikasi baik (B) 0 orang atau $0 \%$, yang masuk klasifikasi sedang (S) ada 20 orang atau $18.52 \%$, yang masuk dalam kalsifikasi kurang ada 37 orang atau $34.52 \%$ dan yang masuk dalam klasifikasi kurang sekali (KS) ada 51 orang atau $47.22 \%$.

Untuk atlet perempuan hasil penelitian menunjukan bahwa dari dari seluruh atlet laki-laki yang berjumlah 108 orang yang masuk dalam klasifikasi baik sekali (BS) 0 orang atau $0 \%$, yang masuk dalam klasifikasi baik (B) 0 orang atau $0 \%$, yang masuk klasifikasi sedang (S) ada 5 orang atau $6.10 \%$, yang masuk dalam kalsifikasi kurang ada 32 orang atau $39.02 \%$ dan yang masuk dalam klasifikasi kurang sekali (KS) ada 54 orang atau $54.88 \%$. 


\section{MEDIKORA Vol. IX, No 1 Oktober 2012}

Berdasarkan hasil penelitian menunjukkan bahwa kebugaran aerobik atlet Puslatda PON DIY tahun 2012 secara umum dalam katagori Kurang. Temuan ini menggambarkan bahwa secara fisik para atlet DIY kurang memadai untuk berlaga di kompetisi PON. Jika ini dikaitkan dengan prestasi dalam PON yang dalam hal ini perolehan medali terutama medali emas, tentu saja berat untuk mendapatkannya.

Ditinjau dari sistem energi, kebugaran aerobik akan menguntungkan bagi atlet yang membutuhkan daya tahan paru jantung seperti lari jauh, jalan cepat, khusus untuk atlet nomor terebut prestasi akan dicapai jika $\mathrm{VO}_{2}$ Max mereka dalam katagori baik atau baik sekali. Tetapi secara umum kebugaran aerobic akan menjadi kondisi fisik dasar yang harus dimiliki oleh semua atlet dalam semua cabang olahraga. Sebagai gambaran perolehan medali para atlet DIY yang berlaga pada PON di Pekan Baru yang berlangsung tgl 10-21 September 2012 adalah 10 emas, 12 perak dan 16 perunggu yang berarti hanya menduduki rangking 14 dari 33 peserta PON dari seluruh Provinsi yang ada di Indonesia.

Banyak faktor yang mempengaruhi kebugaran jasmani seorang atlet, dan biasanya sebagian atlet non aerobik, mengabaikan kondisi kebugaran aerobik karena menganggap tidak penting. Kenyataan di lapangan menunjukkan bahwa meskipun atlet bertanding dengan energi anaerobik atau bahkan lebih mengandalkan sistem ATP-PC, tetapi dalam kejuaraan seperti pada multi event atlet terkadang harus menunggu berjam-jam untuk berlomba dari seri satu ke seri berikutnya. Contohnya untuk atlet aeromodeling, untuk ikut bertanding dalam satu nomor, untuk menyelesaikan pertandingan dalam satu hari dapat bermain sebanyak 7 sesi yang terkadang bisa menghabiskan waktu 4-6 jam, sehingga dalam satu hari seorang atlet harus berada di lapangan menunggu giliran bermain, dan biasnya ada jeda untuk isoma selama 1-2 jam. Dengan demikian meskipun seorang atlet aeromedeling tidak mmerlukan $\mathrm{VO}_{2}$ Max yang tinggi, tetapi untuk bermain dalam waktu ber jam-jam dalam sehari juga diperlukan kebugaran aerobik yang harus dalam klasifikasi sedang atau baik.

\section{KESIMPULAN}

Berdasarkan hasil pembahasan yang dikemukakan di atas, maka kajian ini menyimpulkan bahwa kebugaran aerobik merupakan unsur kondisi fisik umum yang harus dimiliki oleh setiap atlet dalam cabang olahraga. Jika kebugaran aerobik seorang atlet bagus, maka atlet tersebut tidak akan mudah lelah dalam menjalankan latihan atau pun dalam pertandingan. Bagi atlet yang unsur biomotornya dominan aerobik, sebaiknya kebugaran aerobik bergerak antara skala baik dan baik sekali, sedangkan bagi atlet yang 


\section{MEDIKORA Vol. IX, No 1 Oktober 2012}

unsur biomotarnya dominan non aerobik sebaiknya kebugaran aerobiknya dalam skala sedang sampai baik.

\section{DAFTAR PUSTAKA}

Abdulkadir Ateng. (1992). Asas dan Landasan Pendidikan Jasmani.Jakarta : Depdikbud.

Bompa, T.O. (2000). Periodization, Theory and Methodology of Training. $4^{\text {th }}$ ed. Dubuque: Kendall/ Hunt Publishing Company.

Fox, E.L, Kirby, T.E, Fox, A.R. (1987). Bases Of Fitness. New York. Macmillan Publisher Company

Hairy, Junusul. (1989). Fisiologi Olahraga. Jakarta: Depdikbud.

http://www.brianmac.co.uk/vo2max.htm diunduh tgl 21 maret 2012

http://goligog.wordpress.com/2010/07/09/vo2max. diunduh tgl 21 maret 2012

http://en.wikipedia.org/wiki/Physical fitness. diunduh tgl 21 maret 2012

Sajoto, Mochamad (1988). Pembinaan Kondisi Fisik dalam Olahraga. Jakarta: Dirjen Pendidikan tinggi.Depdikbud.

Suharjana. (2012). Klasifikasi Kebugaran Aerobik Atlet Puslatda PON DIY Tahun 2012. Laporan Penelitian, FIK UNY

Sumosardjuno, Sadoso. (1989). Olahraga dan Kesehatan dari A-Z. Jakarta : Pustaka Rini. 